\title{
MENUMBUHKEMBANGKAN JIWA KEWIRAUSAHAAN SISWA DI PONDOK PESANTREN AL-MANAR CIBEUTEUNG UDIK, KECAMATAN CISEENG, KABUPATEN BOGOR
}

\author{
${ }^{1}$ Jamaludin*, ${ }^{2}$ Sirajudin, ${ }^{3}$ Thamrin, ${ }^{4}$ Masran Mustakim, ${ }^{5}$ Jakariah \\ Dosen Ekonomi Fakultas Ekonomi Universitas Pamulang
}

Email: dosen01020@unpam.ac.id, dosen01697@unpam.ac.id, thamrinabdulkadir44@gmail.com, dosen01037@unpam.ac.id, dosen01225@unpam.ac.id

\section{ABSTRAK}

Adapun tujuan dari PKM ini adalah Untuk mengetahui upaya menumbuhkan minat berwirausaha Siswa pada Pondok Pesantren Al-Manar, Untuk mengetahui faktor yang mendukung upaya menumbuhkan minat berwirausaha pada Siswa Di Pondok Pesantren AlManar Cibeuteung Udik Kecamatan Ciseeng Kabupaten Bogor.

Metode yang digunakan dalam PKM ini 1). Metode Ceramah/Presentasi Metode ceramah/presentasi dipilih untuk memberikan penjelasan tentang : a. Memberikan pengetahuan terkait dengan upaya menumbuhkan minat berwirausaha. b. Presentasi mengenai faktor yang mendukung upaya menumbuhkan minat berwirausaha diharapkan mereka bisa mengaplikasikan kedalam kegiatannya dalam bewirausaha; 2). Metode Tanya Jawab, Metode Tanya jawab sangat penting bagi para peserta pelatihan. Metode ini memungkinkan para siswa/i menggali pengetahuan sebanyak- banyaknya tentang menumbuhkan minat berwirausaha, faktor yang mendukung upaya menumbuhkan minat berwirausaha; 3. Sharing Session Tentang Menumbuhkembangkan Jiwa Kewirausahaan

Kesimpulan dari kegiatan PKM ini adalah kewirausahaan dipandang sebagai fungsi yang mencakup eksploitasi peluang-peluang yang muncul di pasar. Eksploitasi tersebut sebagian besar berhubungan dengan pengarahan dan atau kombinasi input yang produktif. Seorang wirausahawan selalu diharuskan menghadapi resiko atau peluang yang muncul, serta sering dikaitkan dengan tindakan yang kreatif dan inovatif. Wirausahawan adalah orang yang merubah nilai sumber daya, tenaga kerja, bahan dan faktor produksi lainnya menjadi lebih besar daripada sebelumnya dan juga orang yang melakukan perubahan, inovasi dan cara-cara baru. Pendidikan kewirausahaan sangat penting bagi manusia, terutama bagi siswa. Kewirausahaan (entrepreneurship) merupakan kemampuan kreatif dan inovaif yang dijadikan sebagai pondasi dan sumber daya untuk mendapatkan peluang dalam meraih kesuksesan. Salah satu fakor yang dapat meningkatkan pendapatan individu/kelompok ialah kewirausahaan. Kewirausahaan juga akan melahirkan kemandirian ekonomi masyarakat. Oleh sebab itu Pendidikan kewirausahaan sangat berpengaruh dalam menghasilkan kreatifitas yang bernilai dan juga pendidikan kewirausahaan adalah sebagai sesuatu yang mendasar dalam meningkatkan kreatifitas siswa.

Kata Kunci: Jiwa Kewirausahaan, Pengembangan Kewirausahaan

\section{ABSTRACT}

The purpose of this PKM is to find out efforts to foster student interest in entrepreneurship at Al-Manar Islamic Boarding School, To find out factors that support efforts to foster entrepreneurial interest in students at Al-Manar Islamic Boarding School in Cibeuteung Udik, Ciseeng District, Bogor Regency.

The method used in this PKM 1). Lecture / Presentation Method The lecture / presentation method was chosen to provide an explanation of: a. Providing knowledge related to efforts to foster entrepreneurial interest. $b$. It is hoped that the presentations on the factors 
that support efforts to foster entrepreneurial interest can be applied in their activities in entrepreneurship; 2). Question and Answer Method, Question and Answer method is very important for the trainees. This method allows students to explore as much knowledge as possible about growing entrepreneurial interest, a factor that supports efforts to foster entrepreneurial interest; 3. Sharing Session About Developing the Spirit of Entrepreneurship

The conclusion of this PKM activity is that entrepreneurship is seen as a function that includes the exploitation of opportunities that arise in the market. The exploitation is mostly related to productive direction and or combination of inputs. An entrepreneur is always required to face risks or opportunities that arise, and often associated with creative and innovative actions. Entrepreneurs are people who change the value of resources, labor, materials and other factors of production to be greater than before and also people who make changes, innovations and new ways. Entrepreneurship education is very important for humans, especially for students. Entrepreneurship (entrepreneurship) is a creative and innovative ability that is used as a foundation and resources to get the opportunity to achieve success. One factor that can increase individual / group income is entrepreneurship. Entrepreneurship will also give birth to community economic independence. Therefore entrepreneurship education is very influential in producing valuable creativity and also entrepreneurship education is something that is fundamental in increasing student creativity.

\section{Keywords: Entrepreneurial Soul, Entrepreneurship Development}

\section{PENDAHULUAN}

Secara harfiah, wirausaha (enterpreneur) terdiri dari kata wira dan usaha. Dalam kamus bahasa Indonesia . (KBI, 2008) wira artinya gagah, luhur, berani,teladan atau pejuang. Sedangkan usaha diartikan sebagai kegiatan komersial atau non komersial/ kegiatan yang dilakukan terus menerus dalam mengelola sumber data untuk menghasilkan barang atau jasa yang akan dijual untuk mendapakan keuntugan. Jadi dapat diartikan wirausaha dapat diartikan sebagai orang yang berjiwa berani mengambil resiko untuk membuka usaha dalam berbagai kesempatan.

Pemahaman kewirausahaan harus dimiliki oleh Siswa karena Siswa sebagai salah satu penerus bangsa diharapkan mampu menjadi tulang punggung negara di kemudian hari. Sehingga dengan pendidikan yang dikuasainya ia mampu menciptakan lapangan kerja, bukan menambah jumlah pengangguran setelah lulus dari sekolah. Jadi, sebisa mungkin seorang siswa dituntut untuk berpikir secara kreatif terhadap peluang bisnis yang ada di masyarakat dan berani mencoba untuk memulai usaha. Jangan bersikap apatis, karena sulit mencari pekerjaan setelah melamar ke mana-mana dan hasilnya selalu nihil. Mereka lupa bahwa sebenarnya bekerja tidak hanya di perusahaan ataupun menjadi pegawai negeri, salah satunya menjadi seorang wirausaha.

Artinya bahwa siswa dituntut untuk berpikir kreatif dalam melihat peluang usaha yang memiliki nilai. Peran siswa sangat penting dalam membangun usaha. Salah satu fakor yang dapat meningkatkan pendapatan individu/kelompok ialah kewirausahaan. Kewirausahaan juga akan melahirkan kemandirian ekonomi masyarakat. Oleh sebab itu Pendidikan kewirausahaan sangat berpengaruh dalam menghasilkan kreatifitas yang bernilai dan juga pendidikan kewirausahaan adalah sebagai sesuatu yang mendasar dalam meningkatkan kemampuan individu. Instruksi presiden Nomor 4 tahun 1995 tentang Gerakan Nasional Memasyarakatkan dan membudayakan kewirausahaan, mengamatkan kepala seluruh masyarakat dan bangsa Indonesia untuk mengembangkan program- program kewirausahaan.

Pemerintah menyadari betul bahwa dunia usaha merupakan tulang punggung perekonomian nasional, sehingga harus diupayakan untuk terus menerus. Melalui gerakan ini diharapkan karakter 
kewirausahaan akan menjadi 2 bagian dari etos kerja masyarakat dan bangsa Indonesia, sehingga dapat melahirkan wirausahawanwirausahawan baru yang handal, tangguh dan mandiri.

Berangkat dari masalah tersebutlah, maka PKM ini mengangkat sebuah tema "Menumbuhkembangkan Jiwa Kewirausahaan Siswa Di Pondok Pesantren Al-Manar Cibeuteung Udik Kecamatan Ciseeng Kabupaten Bogor".

\section{RUMUSAN MASALAH}

Rumusan masalah yang akan di pecahkan melalui program ini pada dasarnya tidak lepas dari ruang lingkup masalah diatas, adapun perumusan masalah dalam kegiatan ini adalah:

1. Bagaimana upaya menumbuhkembangkan minat berwirausaha pada Siswa Di Pondok Pesantren Al-Manar Cibeuteung Udik Kecamatan Ciseeng Kabupaten Bogor?

2. Faktor yang mendukung upaya menumbuhkan minat berwirausaha pada Siswa Pondok Pesantren Al-Manar Cibeuteung Udik Kecamatan Ciseeng Kabupaten Bogor?

\section{TUJUAN PELAKSANAAN}

Adapun tujuan dari pelaksanaan PKM ini adalah sebagai berikut:

1. Untuk mengetahui upaya menumbuhkembangkan minat berwirausaha pada Siswa Di Pondok Pesantren Al-Manar Cibeuteung Udik Kecamatan Ciseeng Kabupaten Bogor;

2. Untuk mengetahui faktor yang mendukung upaya menumbuhkan minat berwirausaha pada Siswa Pondok Pesantren Al-Manar Cibeuteung Udik Kecamatan Ciseeng Kabupaten Bogor.

\section{TINJAUAN PUSTAKA}

\section{A. Pengertian Minat}

Menurut Slamet minat adalah rasa suka dari rasa ketertarikan pada suatu hal atau aktivitas, tanpa ada yang menyuruh. Minat pada dasarnya adalah penerimaan akan suatu hubungan antara diri sendiri dengan sesuatu diluar diri sendiri (Djaali, 2009). Sedangkan menurut Witherington dalam (Ariesta, 2010:18) bahwa minat adalah kesadaran seseorang bahwa suatu objek, seseorang, suatu soal atau suatu situasi mengandung sangkut paut dengan dirinya. Minat terhadap suatu obyek, aktivitas, situasi maupun kepada orang lain, antara individu yang satu dengan individu yang lain dapat berbeda- beda, tergantung seberapa besar ketertarikannya terhadap suatu obyek, aktivitas, situasi ataupun orang lain tersebut

Aspek- aspek dari minat tersebut adalah:

a. Aspek kognitif. Konsep yang dikembangkan mengenai bidang yang disukai. Berdasarkan atas pengalaman pribadi dan apa yang pernah dipelajari baik dirumah, disekolah dan masyarakat serta berbagai jenis media massa.

b. Aspek afektif Konsep emosional yang dinyatakan dalam sikap terhadap yang ditemukan. Pada konsep ini sikap terhadap suatu penemuan menjadi salah satu aspek untuk mendapat sesuatu yang dapat menguntungkan.

Sedangkan menurut Pintrick dan Schunk (1996) mengungkapkan aspekaspek minat sebagai berikut :

1. Sikap umum terhadap aktivitas (general attitude toward the activity), yaitu perasaan suka tidak suka, setuju tidak setuju dengan aktivitas, umumnya terhadap sikap positif atau menyukai aktivitas.

2. Kesadaran spesifik untuk menyukai aktivitas ( specivic for or living the activity), yaitu memutuskan untuk menyukai suatu aktivitas atau objek.

3. Merasa senang dengan aktivitas (enjoyment of the activity), yaitu individu merasa senang dengan segala hal yang berhubungan dengan aktivitas yang diminatinya.

4. Aktivitas tersebut mempunyai arti atau penting bagi individu (personal 
importence or significance of the activity to the individual

5. Adanya minat intriksik dalam isi aktivitas ( intrinsic interes in the content of the activity), yaitu emosi yang menyenangkan yang berpusat pada aktivitas itu sendiri.

6. Berpartisipasi dalam aktivitas (reported choise of or participant in the activity) yaitu individu memilah atau berpartipasi dalam aktivitas.

B. Kewirausahaan

Menurut Kemendiknas

Kewirausahaan merupakan sikap mental dan jiwa yang selalu aktif atau kreatif berdaya, bercipta, berkarya, dan bersahaja, serta berusaha dalam rangka meningkatkan pendapatan dalam kegiatan usahanya.

\section{Menurut}

Kasmir

(2006)

kewirausahaan adalalah suatu kemampuan dalam hal menciptakan kegiatan usaha. Kemampuan menciptakan memerlukan adanya kreatifitas dan inovasi yang terus menerus untuk menemukan sesuatu yang berbeda dari yang sudah ada sebelumnya.

Menurut Muis dkk (2015) Berwirausaha adalah bukan hanya bakat bawaaan sejak lahir namun dapat dipelajari dan diajarkan melalui proses pendidikan formal atau informal. Contohnya setelah perang dunia ke 2 beberapa veteran perang di Amerika belajar berwirausaha, melalui suatu pendidikan atau pelatihan, baik pendidikan/pelatihan singkat maupun pendidikan/pelatihan yang berjenjang. Mereka berusaha dengan modal pengetahuan dan fasilias lainnya.Contoh Samuel Whalton pendiri walmart yang kini menjadi retailer terbesar dunia adalah veteran yang memulai usahanya pada usia 47 tahun. Ross Pero pendiri Texas instrument yang pernah mencalonkan diri sebagai presiden amerika dari partai independen juga seorang veteran yang berhasil dibentuk menjadi wirausaha. Ada yang mengatakan bahwa seseorang menjadi wirausaha karena lingkungan. Misalnya banyak orang WNI keturunan menjadi wirausaha yang sukses karena mereka hidup dilingkungan para wirausaha dan pelaku usaha. Menurut Retno budi lestari dan Trisnati Wijaya dalam Judul "Pengaruh Pendidikan Kewirausahaan Terhadap Minat Berwirausaha Mahasiswa di STIE 8 MDP,dan STIE MUSI "Penelitian di lakukakan di kota Palembang pada mahasiswa yang menempuh mata kuliah kewirausahaan pada semester genap tahun akademik 2010/2011, sebanyak 500 orang terdiri dari 253 mahasiswa dari STIE MDP dan 115 mahasiswa dari STIE MUSI. Pada penelitian ini di pakai instrumen penelitian yaitu, instrumen untuk mengukur sikap pribadi/ kepribadian, norma subjekif, persepsi, control perilaku dan niat dalam berwirausaha. Instrumen penelitian akan terlebih dahulu akan di analisis validitas, dan reliabilitasnya. Pengambilan data primer pada penelitian ini menggunakan instrument kuesioner yang disebar pada pada 3 PTS, dengan jumlah sampel sebanyak 205 responden. Dari penelitian ini, peneliti menyimpulkan bahwa pendidikan kewirausahaan berpengaruh secara signifikan terhadap minat berwirausaha. Pendidikan kewirausahaan yang dimaksudkan adalah proses pembelajaran untuk mengubah sikap dan pola pikir mahasiswa terhadap pilihan karier berwirausaha. Dengan demikian mahasiswa yang telah menempuh mata kuliah kewirausahaan akan memilki nilai-nilai hakiki dan karakteristik kewirausahaan sehingga akan meningkatkan minat serta kecintaan mereka terhadap dunia kewirausahaan. Tingginya minat berwirausaha akan melahirkan entrepreneur- entrepreneur muda yang memiliki visi yang jelas di masa depan, kreatifitas serta inovasi yang tinggi dalam segala bidang. Mereka akan lebih mandiri, kreatif dan inovatif dalam menciptakan peluang bisnis baru dan penemuan-penemuan baru. Masalah 
penggangguran terdidik akan teratasi karena keluaran (output) dari hasil pendidikan kewirausahaan adalah caloncalon enterpreneur muda berbakat yang tidak lagi mencari kerja (job seeker) tetapi telah menjadi pencipta lapangan pekerjaan (job maker). Jadi adapun persaman penelitian ini dengan penelitian yang dilakukan oleh penulis yakni sama- sama merujuk pada pengaruh pendidikan kewirausahaan terhadap peserta didik. Sukirman yang berjudul "Jiwa Kewirausahaan Dan Nilai Kewirausahaan Meningkatkan Kemandirian Usaha Melalui Perilaku Kewirausahaan" Penelitian ini bertujuan untuk menganalisis pengaruh jiwa kewirausahaan dan nilai kewirausahaan terhadap perilaku kewirausahawan untuk menciptakan kemandirian usaha. Metode yang digunakan dalam menganalisis data menggunakan analisis jalur (path analysis). Sampel dalam penelitian ini 125 usaha kecil yang terdiri dari 45 usaha kecil batik pekalongan, 42 usaha kecil makanan khas batu malang dan 38 usaha kecil keramik kasongan bantul Yogyakarta. Analisis data menggunakan Structural Equation Modelling (SEM). Hasil penelitian menunjukan bahwa jiwa kewirausahaan mempuyai pengaruh tidak langsung terhadap kemandirian usaha. Nilai kewirausahawan mempunyai pengaruh secara langsung terhadap perilaku kewirausahaan dan juga berpengaruh secara tidak langsung terhadap kemandirian usaha. Sedangkan perilaku kewirausahaan berpengaruh positif terhadap kemandirian usaha. Adapun persamaan dari penelitian ini dengan yang dilakukan penulis adalah memiliki kesamaan di bagian nilai/pendidikan kewirausahaan. Budi \& Fabianus fensi (2018) 10) dalam jurnal dengan judul, "Pengaruh Pendidikan Kewirausahaan Dalam menumbuhkan Minat perkembangan suatu wilayah, kewirausahaan merupakan salah satu factor penting karena hal itu merupakan penggerak ekonomi suatu wilayah, ketika kewirausahaan suatu wilayah selalu melakukan inovasi atau pembaharuan terhadap barang ataupun jasanya, otomatis dapat meningkatkan income dari wirausahawan itu sendiri dan sekaligus juga dapat meningkatkan pendapatan wilayah tersebut. Indonesia membutuhkan wirausaha 5,8 juta wirausaha baru untuk mencapai rasio wirausaha ideal yaitu 4\% dari jumlah penduduk. Kebutuhan untuk melahirkan kewirausahaan baru ini menyebabkan banyak lembaga pendidikan yang memasukkan pendidikan kewirausahaan dalam kurikulum mereka. Meskipun penelitian tentang kewirausahaan sudah berlangsung cukup lama, namun pendidikan kewirausahaan tetap menjadi perdebatan. Hal ini termasuk sejauh mana pendidikan kewirausahaan memiliki pengaruh terhadap peserta didik, ketepatan dan keefektifan metode pengajaran kewirausahaan, dan perdebatan apakah kewirausahaan dapat diajarkan. Penelitian ini bertujuan untuk menganalisa apakah pendidikan kewirausahaan memilki dampak untuk membangkitkan niat berwirausaha peserta didik. Subjek dalam penelitian ini adalah kelas kewirausahaan.

C. Aspek pengetahuan berwirausaha

Pengetahuan sangat penting bagi manusia terutama bagi siswa dalam menjalankan kewirausahaan.

Di tahap ini siswa diberikan pengetahuan awal tentang ilmu berwirausaha seperti:

a. Business plan. Di tahap ini siswa membuat rencana atau rancangan apa yang akan mereka buat dalam usahanya mulai dari tahap awal hingga akhir dan siswa disini juga melakukan pengamatan pasar/lingkungan. Selain itu juga di bagian business plan ini siswa menyiapkan solusi ketika sesuatu masalah yang tidak inginkan terjadi.

b. Rencana srategis. Di dalam berwirasuha dibutuhkan strategi 
yang jitu atau yang tepat sasaran . Untuk mendukung pengamatan lingkungan/ pasar. Maka diperlukan tindak lanjut dengan siswa melakukan penjaringan pasar. Penjaringan pasar adalah sebuah sebuah versi pengamatan lingkungan dimana wirausahawan/ perusahaan mengidentifikasi pasar-pasar yang diinginkan dengan menggunakan kekuatan-kekuatan lngkungan untuk mengurangi pasar-pasar yang kurang diinginkan

c. Perencanaan merupakan ujung tombak dari kewirausahaan dimana perencanaan itu menentukan hasil yang posiif atau negatif dimasa yang akan datang. Disini siswa di tuntuk untuk melakukan perencanaan usaha apa yang akan mereka buat,dan hal pendukung lainnya. Ketika perencanaan yang dilakukan oleh siswa secara matang otomatis kemungkinan hasil yang mereka dapat dimasa yang akan datang adalah hasil yang positif. Sebaliknya, ketika perencanaan yang dilakukan siswa kurang matang atau mengalami kesalahan, otomatis hasil yang didapat dimasa yang akan datang adalah hasil yang negatif atau melenceng dari target yang di buat atau di inginkan.

\section{HASIL DAN PEMBAHASAN}

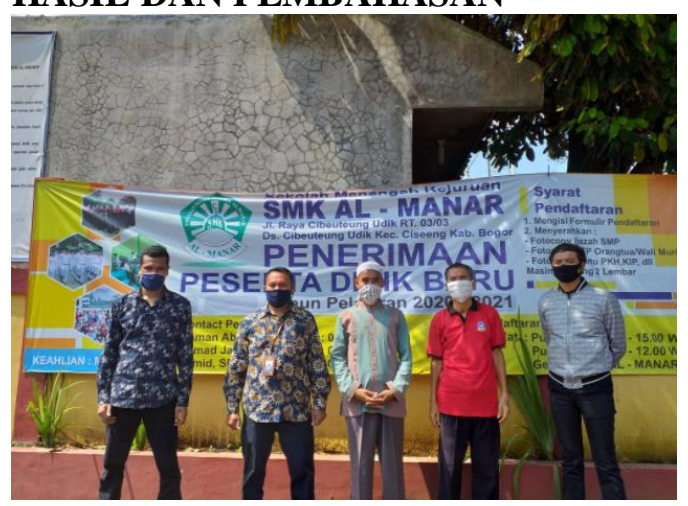

Sumber: dokumentasi saat pelaksanaan PKM.
1. Bagaimana menumbuhkembangkan upaya minat berwirausaha pada Siswa Di Pondok Pesantren Al-Manar Cibeuteung Udik Kecamatan Ciseeng Kabupaten Bogor? Pengembangan wirausaha merupakan tuntutan setiap sekolah untuk dapat mewujudkan kemdandirian siswa. Untuk dapat mengembangkan wirausaha secara eksponansial dibutuhkan suatu strategi yang tepat sasaran dan tepat guna. Strategi dikatakan tepat sasaran dan tepat guna apabila dapat menentukan apa yang harus dikerjakan untuk mencapai suatu tujuan dengan proses yang lebih cepat secara waktu dan lebih efisien secara biaya,dan mampu menciptakan keunggulan bersaing yang berkesinambungan (Alimudin, 2017).

Berikut adalah tips menumbuhkan jiwa wirausaha dalam diri (Masita, 2018) sebagai berikut:

1. Kuatkan tekad dan niat. Hal pertama yang harus kamu lakukan adalah menguatkan tekad dan niatmu. Jangan sampai keinginan untuk menjadi wirausaha hanya karena ikut-ikutan tren atau keinginan sementara saja. Dengan kamu menguatkan tekat dan niat, nantinya kamu akan siap menghadapi segala rintangan dan cobaan yang pasti akan kamu dapatkan selama merintis usaha.

2. Buat target dan rencana masa depan. Target dan rencana akan membuatmu lebih siap membangun usaha. Dengan adanya target dan rencana, kamu juga akan lebih mudah membuat langkah-langkah bisnis yang harus dijalani dan lebih mudah mengukur kinerjanya. Target dan rencana ini juga akan membuatmu lebih termotivasi mendirikan bisnis yang semakin maju dari waktu ke waktu.

3. Miliki ide bisnis. Asah terus idemu untuk mendirikan bisnis. Kamu tidak mungkin bisa menjadi wirausahawan jika tidak memiliki ide bisnis. Tidak perlu melangkah terlalu jauh untuk 
mendirikan bisnis. Kamu bisa memulainya dari hal yang terlihat kecil, namun merupakan hobi dan minatmu. Dengan begitu, kamu bisa memiliki bisnis yang menarik sekaligus menyenangkan untuk kamu lakukan

4. Ukur resiko yang mungkin muncul. Kamu tidak mungkin mendirikan bisnis yang tidak terukur dan tidak kamu ketahui resikonya. Cari tahu resiko bisnis apa yang mungkin muncul sebelum kamu memulai bisnis tersebut. Kamu pun bisa mempersiapkan plan A, plan $B$ dan seterusnya untuk menghadapi resikoresiko tersebut. Dengan kamu mengukur resiko terlebih dahulu sebelum kamu memulai usaha, kamu akan lebih siap jika resiko-resiko tersebut muncul.

5. Pelajari kisah bisnis orang lain. Untuk menumbuhkan jiwa wirausaha, kamu tidak selalu harus belajar dari buku atau pengalamanmu sendiri. Seringkali pengalaman orang lain bisa menjadi pelajaran yang sangat berharga untuk menumbuhkan jiwa wirausaha. Cobalah untuk membaca kisah sukses bisnis orang lain yang juga bisa memberimu pandangan baru dan semangat untuk mendirikan bisnis sendiri.

6. Tumbuhkan rasa optimisPersiapkan mentalmu untuk menghadapi rintangan yang pasti akan kamu alami saat merintis bisnismu nanti. Hal yang paling utama adalah optimisme yang akan membuatmu tetap yakin untuk . melanjutkan bisnis dan mencapai targetmu. Tanpa rasa optimis, kamu akan mudah menyerah dan tidak ingin melanjutkan usaha. Tentu hal ini akan keinginanmu menjadi seorang wirausahawan.

7. Fokus. Di awal kamu sudah memiliki target dan rencana bisnis. Maka, fokuslah pada hal itu. Jangan mudah melirik 'bisnis tetangga' karena hal itu akan membuatmu tidak fokus dan justru mengacaukan rencana awalmu. Dengan kamu fokus pada target dan rencana awal, kamu akan lebih mudah menjalankan step by step rencanamu dan tidak terganggu pikiran yang tibatiba muncul dan membelokkan tujuanmu. Maka, fokuslah pada target dan rencana awal. Fokus tidak berarti kamu hanya melakukan satu hal yang kamu rencanakan saja. Tetap ada kemungkinan buruk di tengah jalan. Namun, dengan kamu fokus pada tujuan yang sudah kamu definisikan di awal, kamu akan lebih bisa mencari solusi jika ada rintangan di tengah perjalanan bisnis. Terus buat perbaikan yang berkelanjutan untuk memperbaiki kualitas bisnismu dan mengembangkannya.

8. Ikuti kelas wirausaha. Kini banyak sekali seminar dan kelas yang dibuat untuk para pemula dalam dunia bisnis. Kelas seperti ini akan sangat bermanfaat untuk kamu ikuti. Kelas wirausaha juga akan memberimu tips menumbuhkan jiwa wirausaha yang mungkin tidak kamu dapatkan di tempat lain. Di sini kamu bisa bertanya langsung kepada para praktisi bisnis dan meminta tips-tips untuk mendirikan bisnis secara langsung pada ahlinya.

9. Tumbuhkan keberanian. Saat kamu memutuskan untuk terjun ke dunia wirausaha, itu berarti kamu sudah siap dengan segala tantangannya. Maka, kamu harus memiliki keberanian sebagai tips menumbuhkan jiwa wirausaha selanjutnya. Jangan mudah terintimidasi dengan bisnis lain atau kompetitor yang lebih berhasil. Jadikan hal tersebut tantangan untuk kamu juga bisa menumbuhkan bisnismu. Dengan memandang persaingan sebagai tantangan, kamu tidak akan mudah takut dan menyerah. Justru, dengan adanya tantangan tersebut kamu akan lebih terpacu untuk lebih berusaha dan 
berkembang demi kemajuan usahamu.

10. Latih kepekaan terhadap peluang bisnis. Sebelumnya sudah disebutkan bahwa kamu harus fokus dalam mengembangkan bisnis yang sudah kamu dirikan. Bukan berarti kamu tidak menerima masukan atau kritik orang lain. Akan tetapi, kamu harus jadikan kritik dan saran tersebut sebagai bahan pengembangan bisnis, bukannya kamu terima mentahmentah untuk menghentikan bisnis yang sedang berjalan dan mendirikan bisnis lainnya. Latih kepekaanmu untuk menangkap kritik dan saran yang kamu terima sebagai peluang baru yang bisa kamu aplikasikan ke bisnismu saat ini. Yang terpenting, jangan menganggap kritikan dari orang lain sebagai ejekan atau sesuatu yang akan membuatmu down.

2. Faktor yang mendukung upaya menumbuhkan minat berwirausaha pada Siswa Pondok Pesantren AlManar Cibeuteung Udik Kecamatan Ciseeng Kabupaten Bogor?

Menurut Suryana (2003) dalam Savitri dan Wanta $(2018,101)$ Berikut adalah karakteristik sikap dan perilaku yang diperlukan agar kewirausahaan dapat berhasil adalah sebagai berikut:

1. Memiliki komitmen yang tinggi dan tekad yang bulat untuk mencurahkan semua perhatiannya pada usaha. Keberhasilan dalam berbisnis didukung oleh rasa tekad yang kuat dan komitmen yang tinggi.kemampuan dalam menjaga komitmen menjadi modal awal untuk memulai usaha;

2. Memiliki rasa tanggung jawab baik dalam mengendalikan sumber daya yang digunakan maupun tanggung jawab terhadap keberhasilan berwirausaha. Setiap pekerjaan yang dilakukan harus didasari oleh tanggung jawab, kemampuan dalam memenuhi setiap tanggung jawab akan berdampak pada kemampuan dalam mengontrol diri sehingga minat untuk berwirausaha menjadi tinggi pula;

3. Berambisi untuk selalu mencari peluang, keberhasilan wirausaha selalu diukur dengan keberhasilan untuk mencapai tujuan. Seorang wirausaha harus memiliki rasa ambisi, hal ini berpengaruh pada capaian dari tujuan yang diinginkan dan dapat terlaksana;

4. Tahan terhadap risiko dan ketidakpastian; seorang pebisnis selalu bersahabat dengan ketidakpastian, karena usaha pasti ada pasang dan surutnya.

5. Percaya diri yang kuat, ia cenderung optimis dan memiliki keyakinan yang kuat terhadap kemampuan yang dimilikinya untuk berhasil. Kepercayaan diri yang kuat akan memberikan motivasi sendiri bagi tercapainya tujuan usaha, orang yang memiliki kepercayaan diri pasti mampu untuk menghadapi setiap masalah yang ada;

6. Memiliki kreativitas yang tinggi dan luwes. Kreativitas merupakan kunci utama dalam bisnis, semakin tinggi kreativitas yang diciptakan tentunya akan mampu untuk meningkatkan penjualan, selain itu kemampuan wirausaha terus digali hingga menciptakan hasil karya yang akan berkualitas tinggi pula. Selain kreativitas, keluwesan wirausaha menjadi pelengkap untuk memberikan pelayanan terbaik dalam memberikan kepuasan;

7. Selalu memerlukan umpan balik yang segera. Berhasil atau tidaknya sebuah usaha dapat dilihat dari kemampuan wirausaha dalam melaksanakan umpan balik yang diberikan dari konsumen dan bersifat segera. Hal ini diperlukan untuk melakukan evaluasi dari hasil kerja yang telah dilakukan dalam berbisnis 
dan menjadi tolak ukur untuk menjadi lebih baik dari sebelumnya;

8. Memiliki tingkat energi yang tinggi, wirausaha yang berhasil biasanya memiliki daya juang yang lebih tinggi dibanding rata-rata orang lainnya, sehingga ia lebih suka kerja keras walaupun dalam waktu yang relatif lama;

9. Memiliki semangat kerja yang tinggi dan tidak mudah putus asa;

10. Berorientasi pada masa yang akan datang, untuk tumbuh dan berkembang, ia selalu berpandangan jauh ke masa depan yang lebih baik;

11. Belajar dari kegagalan, wirausaha yang berhasil tidak pernah takut gagal. la selalu memfokuskan kemampuannya pada keberhasilan;

12. Memiliki keterampilan memimpin orang lain.

\section{KESIMPULAN DAN SARAN \\ Kesimpulan}

Dalam memasuki dunia kewirausahaan siswa diuntut untuk tidak hanya memilki kemampuan tetapi siswa harus memiliki ide dan kemauan, ide dan kemauan itulah yang akan di wujudkan dalam bentuk penciptaan atau pembuatan barang dan jasa yang laku dipasar.

Hal ini merupakan hasil dari kreatifitas. Selain itu, modal dibutuhkan dalam berwirausaha. Dalam hal ini modal yang dimaksud bukan hanya berupa uang tetapi juga bisa berupa barang, orang (tenaga kerja/skill) dan juga bisa berupa fasilitas. Selanjunya Barang dan jasa , Dalam menentukan barang dan jasa yang akan dijadikan sebagai objek kewirausahaan tentunya siswa harus memiliki pasar( konsumen dan laku dipasarkan) untuk memasarkan produk/jasa tersebut.

Kemudian adapun hal tambahan yang harus di perhatikan siswa dalam berwirausaha yakni Pasar. Siswa sebelum menciptakan produk harus mengamati peluang pasar yang sedang banyak diminati oleh konsumen. Dan yang terakhir adalah
Provit, bila siswa sudah melihat peluang pasar maka tinggal memproduksi barang/produk yang telah di tentukan sebagai sasaran kewirausahaan.Produk/barang ini merupakan hasil kreatifitas siswa dengan melihat berbagai macam factor kewirausahaan untuk meningkatkan keuntungan dalm berwirausaha.

Dari hasil PKM tentang Menumbuhkembangkan Jiwa Kewirausahaan Siswa Di Pondok Pesantren Al-Manar Cibeuteung Udik Kecamatan Ciseeng Kabupaten Bogor disimpulkan sebagai berikut:

1. Para pesera mendapakan pendalamaman ilmu terkait kewirausahaan dan cara menumbuhkan jiwa wirausaha dalam diri.

2. Adanya peningkatan pengetahuan para peserta terkait cara membangun Kewirausahaan yang baik terutama bagi siswa/i yang belum pernah membuat perencanaan bisnis dan belum memilki usaha.

3. Para peserta merasa puas dengan materi yang diberikan oleh para dosen universitas pamulang, hal ini dilihat dari keseriusan dalam mengikuti acara PKM.

\section{Saran}

Saran untuk kegiatan PKM kedepanya adalah sebagai berikut:

1. Perluya diberi dukungan terus menerus kepada siswa supaya termotivasi dalam menggali minat berwirausaha dalam diri siswa..

2. Kedepannya bisa terjadi kolaborasi kegiatan lain antara pesantren Al- manar dengan Universitas Pamulang dan mendatangkan para Pengusaha yang sukses

3. siswa/ peserta didik perlu belajar tentang kewirausahaan sejak dini

4. melatih siswa menuangkan ide dalam membuat kreatifitas atau inovasi terhadap barang dan jasa, membentuk kemandirian, melatih siswa besosialisasi dengan lingkungan, dan yang paling utama adalah membangkitkan niat berwirausaha. 


\section{DAFTAR PUSTAKA}

Alimudin, Arasy. "Strategi Pengembangan Minat Wirausaha Melalui Proses Pembelajaran" Jurnal. E-ISSN : 2407$7305 . \quad$ e-Jurnal Manajemen Kinerja.https://journal.unnes.ac.id/nju/ index.php/DP/article/view/4926/4074. Universitas Negeri Semarang and ASPROPENDO, APRODIKSI, ASPAPI.

Budi\&Fensi, F (2018). Kewirausahaan Dalam menumbuhkan Minat Berwirausaha. Jurnal Pengabdian dan Kewirausahaan (Online). Universitas Bunda Mulia. Jakarta. Vol 2. https://journalubm.ac.id/index.php/pen gabdiandankewirausahaan/article/view /1128/989. 22 oktober 2019.

Djaali. 2009. Pikologi Pendidikan. Jakarta: Bumi Aksara.

Masita, Hana. 2018. "10 Tips Menumbuhkan Jiwa Wirausaha" Artikel Dosen Psikologi.com. https://dosenpsikologi.com/tipsmenumbuhkan-jiwa-wirausaha.

Kasmir. 2006. Kewirausahaan . Jakarta. Rajawali Pers

Muis, A dkk. 2014. Ibk Pengembangan Kewirausahaan Bagi Mahasiswa dan Alumni di Universita Muhammadiyah Parepare. Jurnal Kemandirian. https://www.academia.

Edu/30603803/ibk_pe. 1 Desember 2019.

Savitri dan Wanta, 2017. "Upaya Menumbuhkan Minat Berwirausaha Pada Mahasiswa Prodi Manajemen Di Ubp Karawang". Vol 3 No 1 (2017): Jurnal Manajemen \& Bisnis Kreatif.http://journal.ubpkarawang.ac. id/index.php/Manajemen/issue/view/2 9

Pasaribu, V. L. D., Agrasadya, A., Shabrina, N., \& Krisnaldy, K. (2020). MENJADI
ENTERPRENEUR MUDA YANG MEMILIKI JIWA LEADERSHIP UNTUK MENGHADAPI MASA DEPAN. Abdi Laksana, 1(1)

Pasaribu, V. L. D., Elburdah, R. P., Sudarso, E., \& Fauziah, G. (2020). PENGGUNAAN MANAJEMEN WAKTU TERHADAP PENINGKATAN PRESTASI BELAJAR DI SMP ARAISIYAH. Jurnal ABDIMAS, 1(1)

Pasaribu, V. L. D., Susanti, F., \& Hartuti, E. T. K. (2019). MEMOTIVASI SISWA DAN SISWI SMK LETRIS INDONESIA DI DALAM MENENTUKAN PILIHAN UNTUK MELANJUTKAN PENDIDIKAN ATAU BEKERJA SETELAH LULUS SEKOLAH. Jurnal Pengabdian Dharma Laksana, 1(2), 161-172.

Pasaribu, V. L. D., Oktrima, B., Prabowo, B., Arianto, N., \& Haryoko, U. B. (2020). PROGAM PENDAMPINGAN DAN PENYELENGGARAAN PENDIDIKAN ANAK PADA USIA DINI TERHADAP PRESTASI BELAJAR DILINGKUNGAN RT 020 RW 009. KEL GIRI PENI. KEC WATES. YOGYAKARTA. JURNAL LOKABMAS KREATIF, 1(1), 71-75.

Pasaribu, V. L. D., Sulaiman, S., Sutiman, S., Thaharudin, T., \& Purnomo, B. Y. (2020). PENGENALAN LETAK POSYANDU TERDEKAT DIKELURAHAN PIS ANGAN DENGAN MANAJEMEN PEMASARAN REVOLUSI 4.0 UNTUK MENINGKATKAN PENGETAHUAN MASYARAKAT LETAK DAN FUNGSI POSYANDU TERDEKAT PADA KELURAHAN PISANGAN. DEDIKASI PKM, 1(1), 105-110.

Pasaribu, V. L. D., \& Krisnaldy, K. (2019). Manajemen Risiko dan Asuransi. 
Loyalitas Kreativitas

Aldi Masyarakat Kreatif
P-ISSN 2722-2101, E-ISSN 2722-4201

Program Studi Ekonomi Manajemen Universitas Pamulang Jurnal LOKABMAS Kreatif Vol. 01, No. 02, Hal. 62-72 Email:jurnalkreatif.manajemen@gmail.com

\section{DOKUMENTASI FOTO KEGIATAN}

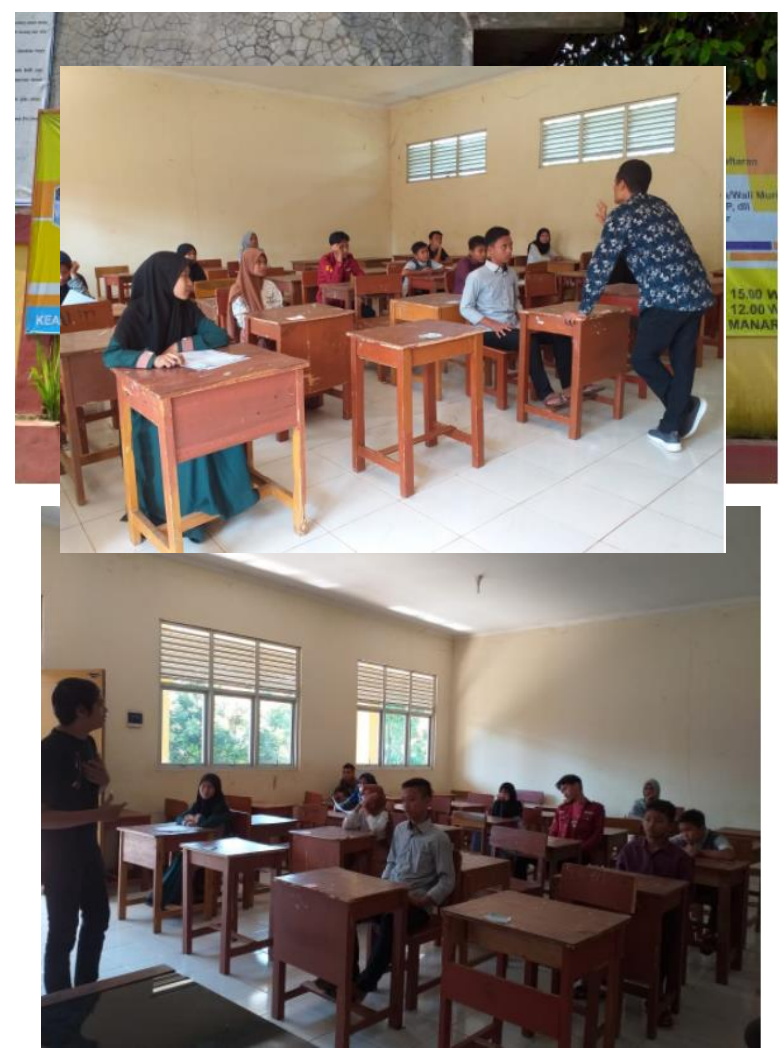

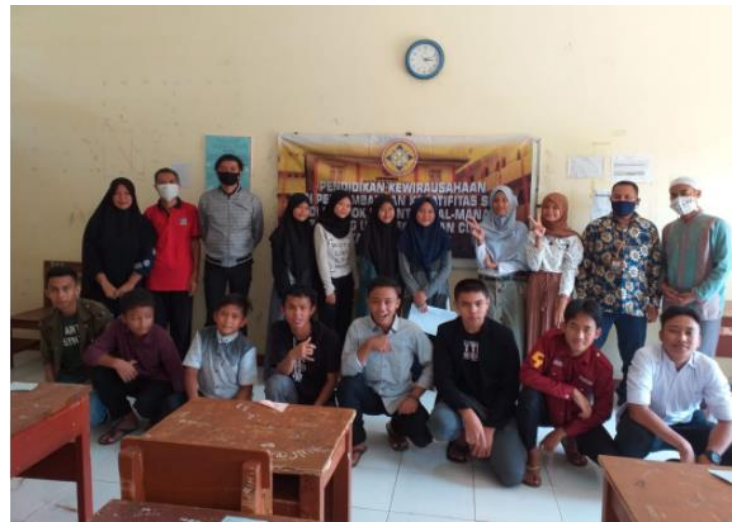

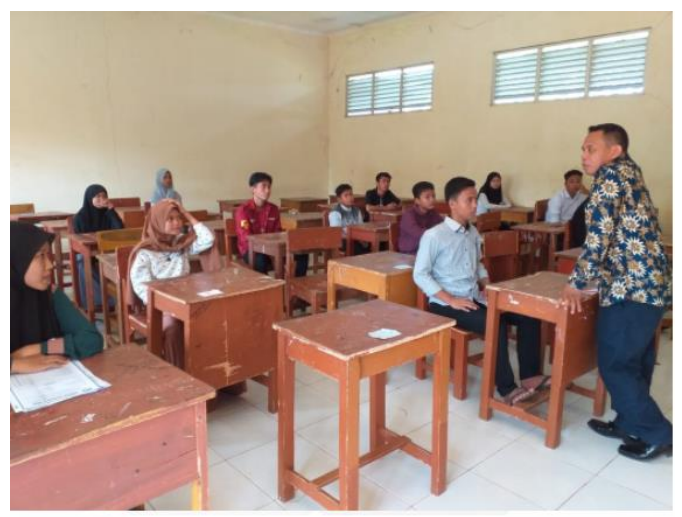

